\title{
Valorization of the Macroalgae Sargassum Muticum by Enzymatic Hydrolysis, Interest of Surfactants to Improve the Extraction of Phlorotannins and Polysaccharides
}

\author{
Laurent Vandanjon ${ }^{2,4^{*}}$, Laurent Vallet ${ }^{1,2}$, Titouan Le Glatin ${ }^{1}$, Paul Deleris ${ }^{1}$, Regis Baron ${ }^{3}$, Patrick \\ Bourseau $^{2,5}$, Justine Dumay ${ }^{1}$ \\ ${ }^{1}$ Université de Nantes, MMS, rue de la Houssinière, Nantes, France \\ ${ }^{2}$ Université de Nantes, GEPEA, Boulevard de l'Université, Saint-Nazaire, France \\ ${ }^{3}$ IFREMER, Laboratoire BiorafHE, Unité Biotechnologie et Ressources Marines, Rue de l'Ile d'Yeu, Nantes, France \\ ${ }^{4}$ Université de Bretagne Sud, LBCM, Rue Saint-Maudé, Lorient, France \\ ${ }^{5}$ Université de Bretagne Sud, IRDL, Rue Saint-Maudé, Lorient, France
}

*Corresponding author: Laurent Vandanjon, Université de Nantes, GEPEA, Boulevard de l'Université, Saint-Nazaire, France: 44600, Université de Bretagne Sud, LBCM, Rue Saint-Maudé, Lorient, France: 56100, Tel: 33.2.97.01.71.25;

E-mail: laurent.vandanjon@univ-ubs.fr

\begin{abstract}
The use of surfactants to improve enzymatic hydrolysis of the macroalgae Sargassum muticum has been investigated. Visible absorption spectroscopy has been used to quantify the solubilization of both polysaccharides and phlorotannins in the hydrolysates.

After total extraction, results showed that Sargassum muticum contained $2.74 \%$ (expressed in percent of the dry weight of the algae) of phlorotannins whose $32 \%$ were in the cell wall. This result shows that it is important to access to the parietal phlorotannins. To reach this objective, we chose the enzymatic approach for destructurating the cell wall of the algae. The use of 5\% dry weight (DW - 5\% by weight of hydrolyzed algae) of an enzymatic mix containing a commercial beta-glucanase, a commercial protease and an alginate lyase extracted from Pseudomonas alginovora led after 3 hours of hydrolysis to the solubilization of $2.43 \% \mathrm{DW}$ polysaccharides and $0.52 \% \mathrm{DW}$ phlorotannins. The use of $0.5 \%$ volume of the surfactant Triton ${ }^{\circledR}$ X-100 with $10 \%$ DW of the enzymatic mix has allowed to reaching the value of $2.63 \% \mathrm{DW}$ of solubilized phlorotannins, that is $96 \%$ of the total phenolic content.

The use of non-ionic surfactant, combined to enzymatic hydrolysis, showed an increased efficiency in disrupting cell wall and solubilizing phlorotannins in Sargassum muticum.
\end{abstract}

Received date: April 26, 2016
Accepted date: May 10, 2016
Published date: May 12, 2016

Citation: Vandanjon, L., et al. Valorization of the Macroalgae Sargassum muticum by Enzymatic Hydrolysis, Interest of Surfactants to Improve the Extraction of Phlorotannins and Polysaccharides. (2016) J Marine Biol Aquacult 2(1): 1- 7.

DOI: $10.15436 / 2381-0750.16 .014$

\section{Introduction}

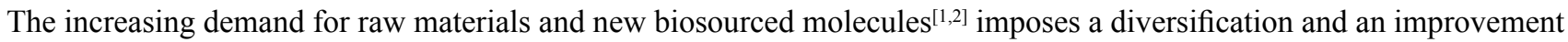
of the valorization of seaweeds ${ }^{[3]}$. For now representing a phycocolloid market and a human and agri-food market ${ }^{[4]}$, seaweeds are expanding their field of use on a global scale ${ }^{[5]}$. This industrial development is encouraged by the great biodiversity and chemodiversity $^{[6]}$ found among marine macroalgae as much as the growing number of scientific publications on their biorefinery ${ }^{[7-10]}$. Sargassum muticum (Yendo) Fensholt is a fast growing brown algae that represents an important and non-valorized biomass. Originally from Japan, this algae spread along European Atlantic coasts during the last 40 years ${ }^{[11]}$. Some other species of Sargassum also constitutes a serious problem in Central America and Antilles. Those characteristics of Sargassum muticum make it a good candidate for investigating the valorization of brown algae. Brown algae (phaeophyceae) contain phlorotannins, polysaccharides (such as alginic acids and sulfated fucans) and pigments (such as the fucoxanthin) that could constitute several bioactive fractions ${ }^{[2,13]}$ out ${ }{ }^{~}$ the valorization process. Among those molecules, phlorotannins were the primary targets of our study. Phlorotannins are a family of 
secondary metabolites found in brown algae, composed of polymers of phloroglucinol units. The phloroglucinol units are linked by aryl and/or diaryl ether bonds to form phenolic structures from $126 \mathrm{Da}$ to $650 \mathrm{kDa}$. Brown algal extracts containing phlorotannins proved to have a range of biological activities as wide as their molecular sizes. Studies showed that phlorotannins have anti-diabet$\mathrm{ic}^{[14,15]}$, anti-oxidation ${ }^{[16]}$, anti-cancer ${ }^{[17]}$, anti-HIV ${ }^{[18]}$ and anti-hypertension ${ }^{[19]}$ effects. Phlorotanninsin algal cells can be divided in two separate fractions. The first fraction, often called cytosolic or soluble, is located within vesicles called physodes ${ }^{[20]}$. The second fraction is constituted by the content of those physodes once it is exuded and becomes a component of the algal cell wall ${ }^{[21]}$. The aim of this work was then to investigate on an efficient (and eco-friendly as much as possible) process that could extract those two pools of phlorotannins from Sargassum muticum.

Enzyme assisted extraction of metabolites and compounds from seaweeds is a green and accurate approach that can be included in extraction processes in the same way it is used on terrestrial plants ${ }^{[22]}$. The use of enzymes allows the hydrolysis of specific links in the matrix of polysaccharides of the algal cell wall. Deniaud-Bouët et $a l^{[23]}$ Proposed an hypothesis concerning the structure of that matrix. Their work tends to show that phlorotannins once bound to the cell wall, are linked to alginic acid. Moreover, the use of surfactants has already been documented for phlorotannins solubilization in seaweeds ${ }^{[24]}$ and for improving enzymatic reaction like hydrolysis of cellulose ${ }^{[25]}$.

In this study, we focused on trying to hydrolyze the cell wall for solubilizing originally bound phlorotannins. The time of hydrolysis and the enzyme/substrate ratio were the parameters tested along with the use of surfactant to enhance the solubilization of phlorotannins. Finally, we tested the effect of four different surfactants widely used for their properties to help cellular lysis and macromolecules solubilization to determine which one works better with this purpose. Those surfactants are the Sodium Dodecyl Sulfate (SDS), the polysorbate 20 (Tween $\left.{ }^{\circledR} 20\right)$ and 80 (Tween $\left.{ }^{\circledR} 80\right)$ and the Triton ${ }^{\circledR} \mathrm{X}-100$.

\section{Materials \& Methods}

\section{Raw Material}

Algae sampling was done in PiriacS/Mer (France), on the zoom site (47 22’38.0'N 2³3’20.4” W). The algae were harvested in July due to the highest phenolic content of Sargassum muticum in summer ${ }^{[26]}$.

\section{Pre treatment Process}

Unrinsed algae were cleaned of epibiota and macrofauna, vacuum packaged and stored at $-80^{\circ} \mathrm{C}$ before being freeze-dried (in an Edwards ${ }^{\circledR}$ Super Modulyo) during 72 hours and cryogrinded. A knife mill IKA ${ }^{\circledR}$ A11 basic was used to obtain the finest powder for the total extraction of phlorotannins.

\section{Biochemical characterization}

Mineral content was determined by weighting the remains of 3 freeze-dried samples after incineration at $400^{\circ} \mathrm{C}$ during 24 hours.

Total sugars extraction was made in alkaline conditions by the Dubois colorimetric method ${ }^{[27]} .1 \mathrm{ml}$ of $\mathrm{NaOH} 1 \mathrm{M}$ was added to $15 \mathrm{mg}$ of dried and grinded algae. The hydrolysis lasted 6 minutes at $90^{\circ} \mathrm{C}$, then the tubes were cooled down before the Dubois assay was performed.

The standard range was made with anhydrous D-Glucose (from 0 to $100 \mu \mathrm{g} \cdot \mathrm{mL}^{-1}$ ). $200 \mu \mathrm{L}$ of phenol 5\% (w:v) was added to $200 \mu \mathrm{L}$ of standard or diluted sample ; $1 \mathrm{ml}$ of sulfuric acid $97 \%$ was added to the mix. The obtained solution was incubated 10 minutes at room temperature, stirred, and then incubated 30 minutes at $30^{\circ} \mathrm{C}$. The optical density was measured at $490 \mathrm{~nm}$ for each triplicate.

The total nitrogen content was determined by using the Kjeldahl method ${ }^{[28]}$. The samples were derivatized with the EZ:Fast kit from Phenomenex and analyzed in gas chromatography. The nitrogen to protein conversion factor used was 5.38 according to Lourenço et al ${ }^{[29]}$.

Total phlorotannins extraction was made according to Koivikko et $a l^{[30]}$. The soluble phlorotannins were extracted with $1 \mathrm{~mL}$ of acetone $70 \%$ for $20 \mathrm{mg}$ of freeze dried and grinded algae at $40^{\circ} \mathrm{C}$ and with constant stirring during 1 hour. This extraction was made 3 times. Samples were centrifuged ( 5 minutes at 20,000 g) and the pellet was washed during 15 minutes under stirring with Methanol (one time); Water (3 times); Methanol (5 times); Dimethylcarbonate (2 times) and finally with Diethyl ether (2 times). After each washing the sample was centrifuged and the supernatant discarded. After the total washing process the pellet was dried at $60^{\circ} \mathrm{C}$ during 1 hour and $1 \mathrm{~mL}$ of $\mathrm{NaOH} 1 \mathrm{M}$ at $80^{\circ} \mathrm{C}$ was added to the pellet for the extraction of the insoluble phlorotannins.

The spectrometric determination of phlorotannins was determined by a modified method of Folin-Ciocalteu using phloroglucinol (purchased from Acros Organics) as a standard phenolic compound. $10 \mu \mathrm{L}$ of Folin-Ciocalteu reagent was added to 20 $\mu \mathrm{L}$ of standard or diluted sample in a 96 wells micro plate; $170 \mu \mathrm{L}$ of $\mathrm{Na}_{2} \mathrm{CO}_{3} 5 \% \mathrm{w} / \mathrm{v}$ was added to each well. After 10 minutes of incubation at $70^{\circ} \mathrm{C}$ the absorbance was measured at $750 \mathrm{~nm}$.

The Lipid content was determined by the method of Folch et al ${ }^{[31]}$. The extraction was made on $1 \mathrm{~g}$ of dried algae rehydrated in $4 \mathrm{~mL}$ of distilled water or $5 \mathrm{~g}$ of fresh algae with $100 \mathrm{~mL}$ of chloroform/methanol (50/50) under stirring. Then $\mathrm{KCl} 0.9 \%(\mathrm{v} / \mathrm{v})$ was added. After decanting, the organic phase was dried under air flow and the extract obtained was weighted.

\section{Enzymatic hydrolysis}

The enzymatic mix used contains one extracted and two commercial enzymes. The commercial enzymes were kindly 
purchased from Novozymes. The Protamex ${ }^{\circledR}$ is a peptidase (EC 3.4.21.62, EC 3.4.24.28) and the Ultraflo XL ${ }^{\circledR}$ is a $\beta$-glucanase (EC 3.1.2.8, EC 3.2.1.6, EC 3.2.1.4). The alginate lyase (EC 4.2.2.3, EC 4.2.2.11) was obtained from the CEVA (Pleubian, France) and was produced from the marine aerobic bacterium Pseudomonas alginovora. All enzymatic hydrolysis were conducted on $1 \mathrm{~g}$ of

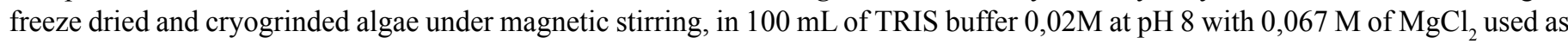
a catalytic agent (as recommended in the patent WO1998040511) for the alginate lyase. Unless mentioned otherwise, the operating conditions were: $2 \% \mathrm{DW}$ of each commercial enzyme, $1 \% \mathrm{DW}$ of alginate lyase, $40^{\circ} \mathrm{C}, 3$ hours of hydrolysis.

\section{Surfactants}

Triton $^{\circledR}$ X-100 was purchased from Koch-Light laboratories, Tween ${ }^{\circledR} 20$ from Laboratoires Humeau, SDS from Fluka Biochemika and Tween ${ }^{\circledR} 80$ from Aldrich laboratories. $0.5 \%(\mathrm{v} / \mathrm{v})$ of surfactant was used in the buffer during the experiment of testing the effect of each surfactant upon the solubilization of the constitutive elements of the algae. During that hydrolysis, $1 \% \mathrm{DW}$ of each enzyme was used. The structures and properties of the surfactants are detailed in the Table 1.

Table 1: Data from Eriksson et al (2002) ${ }^{[35]}$; Types: A, negatively charged; N, non-ionic; M, relative molecular mass of monomer; CMC, critical micelle concentration; HLB, hydrophilic-lipophilic balance.

\begin{tabular}{|c|c|c|c|c|c|}
\hline & Structure & Type & M (monomer) & CMC (mM) & HLB \\
\hline SDS & & A & 288 & 8.1 & 40 \\
\hline Triton X-100 & & $\mathrm{N}$ & 628 & 0.31 & 13.5 \\
\hline Tween 20 & & $\mathrm{~N}$ & 1228 & 0.059 & 16.7 \\
\hline Tween 80 & & $\mathrm{~N}$ & 1310 & 0.01 & 15 \\
\hline
\end{tabular}

\section{Statistics}

All statistical analysis were done with the software Minitab 16. A single factor-ANOVA was followed by a Tukey test. The letters a, b, c, d, e discriminate significantly different clusters.

\section{Results}

The results are expressed in percent of the dry weight of the algae. As preliminary data, we performed a partial biochemical characterization of our dried samples of Sargassum muticum. Results have shown that the samples contained $33 \pm 0.2 \%$ ash, 2.86 $\pm 0.14 \%$ lipids and $7.75 \pm 0.2 \%$ proteins $(1.44 \pm 0.036 \%$ nitrogen $)$. The aminogram showed that half of the amino acids quantified were Glutamic acid (Glu), Alanine (Ala), Aspartic acid (Asp), Leucine (Leu) and Glycine (Gly). After alkaline extraction, the content of total polysaccharides was $6.3 \pm 0.4 \%$. The total extraction of phenolic compounds reached $2.74 \pm 0.17 \%$. These data have helped us comparing our samples of Sargassum muticum to other biochemical characterizations and to values obtained during the optimization of enzymatic hydrolysis.

The total quantification of phenolic compounds (Figure 1) in Sargassum muticum (sample from July) showed a value of $32 \%$ (equal to $0.88 \pm 0.05 \% \mathrm{DW}$ of the total algae sample) for the quantification of insoluble phenolics bound to the cell wall against $68 \%(1.86 \pm 0.12 \% \mathrm{DW})$ of soluble phenolics contained in the cytosol. Both the fractions are important, and so the use of enzymes is necessary to solubilize the maximum of phlorotannins. 


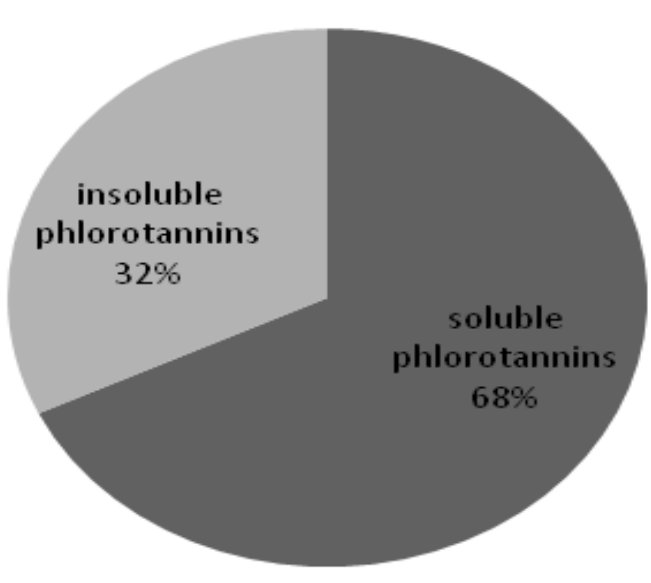

Figure 1: Results of the total quantification and repartition of the phlorotannins in Sargassum muticum.

\section{Enzymatic Hydrolysis}

Solubilization of polysaccharides (Figure 2)

The hydrolysis of the cell wall of the algae was monitored by the solubilization of total sugars in the hydrolysate. The percentages were calculated by dividing the sugar content by the total algal dry weight hydrolyzed (1g). After 3 hours of hydrolysis with $5 \%$ DW of enzymes (2\% Protamex, $2 \%$ Ultraflo XL, $1 \%$ Alginate lyase) the amount of solubilized sugars $(2.43 \pm 0.12 \%)$ was not significantly higher than the control $(2.28 \pm 0.01 \%)$ as shown by the Tukey test. However, the quantity of solubilized sugars depends on the enzyme/substrate ratio with a significant increase between 5\% and $10 \%$ of enzymes $(2.6 \pm 0.007 \%$ for $4 \%$ Protamex, $4 \%$ Ultraflo XL and 2\% Alginate lyase). This increase in the solubilization of total sugars in the hydrolysate can be the sign of the enzymatic degradation of the algal cell wall.

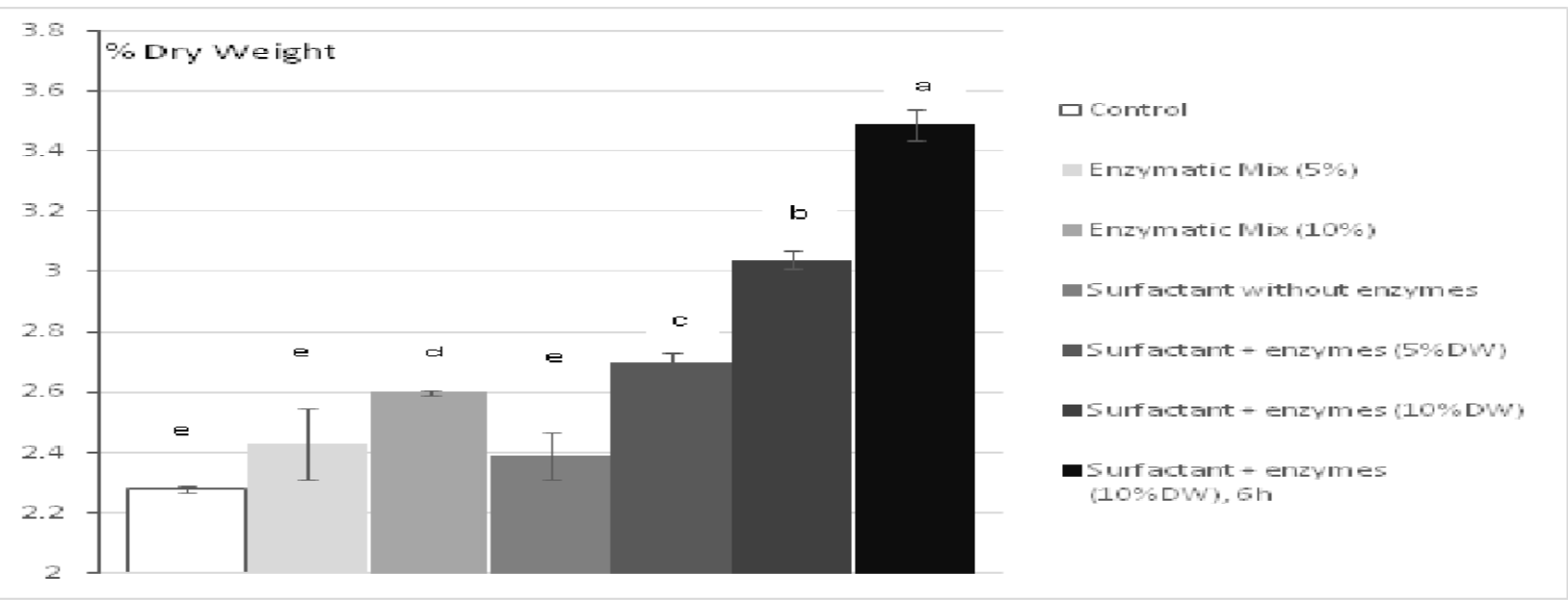

Figure 2: Effect of Triton X-100 (0.5\% vol.) on the solubilization of total sugars (quantified by the method of Dubois). Each bar represents a triplicate. Letters discriminate significantly different values.

Then, $0.5 \%(\mathrm{v} / \mathrm{v})$ of Triton X-100 was used in the reactor. The presence of surfactant only has not constituted a significant enhancement for the solubilization of total polysaccharides $(2.39 \pm 0.08 \% \mathrm{DW})$. However, a synergy between the enzymes and the surfactant for the hydrolysis of polysaccharides has been observed with a value of $2.70 \pm 0.03 \%$ DW with $5 \%$ of enzymes (vs. $2.43 \%$ without surfactant), and a value of $3.04 \pm 0.03 \%$ DW with $10 \%$ of enzymes (vs. $2.6 \%$ without surfactant). This increased efficiency has seemed to be also dependent from the time of hydrolysis $(3.49 \pm 0.05 \% \mathrm{DW}$ with 6 hours of hydrolysis), whereas this time dependent solubilization of neutral sugars is not observed in the control hydrolysis (without any enzyme) where the quantity of solubilized sugars reaches a limit before 3 hours of maceration.

\section{Solubilization of phenolic compounds (Figure 3)}

The observations for the solubilization of phlorotannins are quite different. The solubilization of phlorotannins by enzymatic hydrolysis is not significantly different with $5 \%$ of enzymes $(0.52 \pm 0.09 \%)$ or even $10 \%$ of enzymes $(0.6 \pm 0.09 \%)$ from the control $(0.44 \pm 0.02 \%)$. Then, we tried to use surfactant to observe its effect on both the degradation of the cell wall and the solubilization of phlorotannins. The value of solubilized phlorotannins with $0.5 \%(\mathrm{v} / \mathrm{v})$ of Triton X-100 without enzyme is already significantly higher $(1.22 \pm 0.11 \%)$ than the values with $5 \%$ or $10 \%$ of enzymes alone. Moreover, a boosting effect of the enzymatic activity can be observed in presence of surfactant since a maximum value of $2.63 \pm 0.47 \%$ DW (after 3 hours) or $2.83 \pm 0.42 \%$ DW (after 6 hours) of solubilized phenolic compounds can be reached with $10 \%$ of enzymes. 


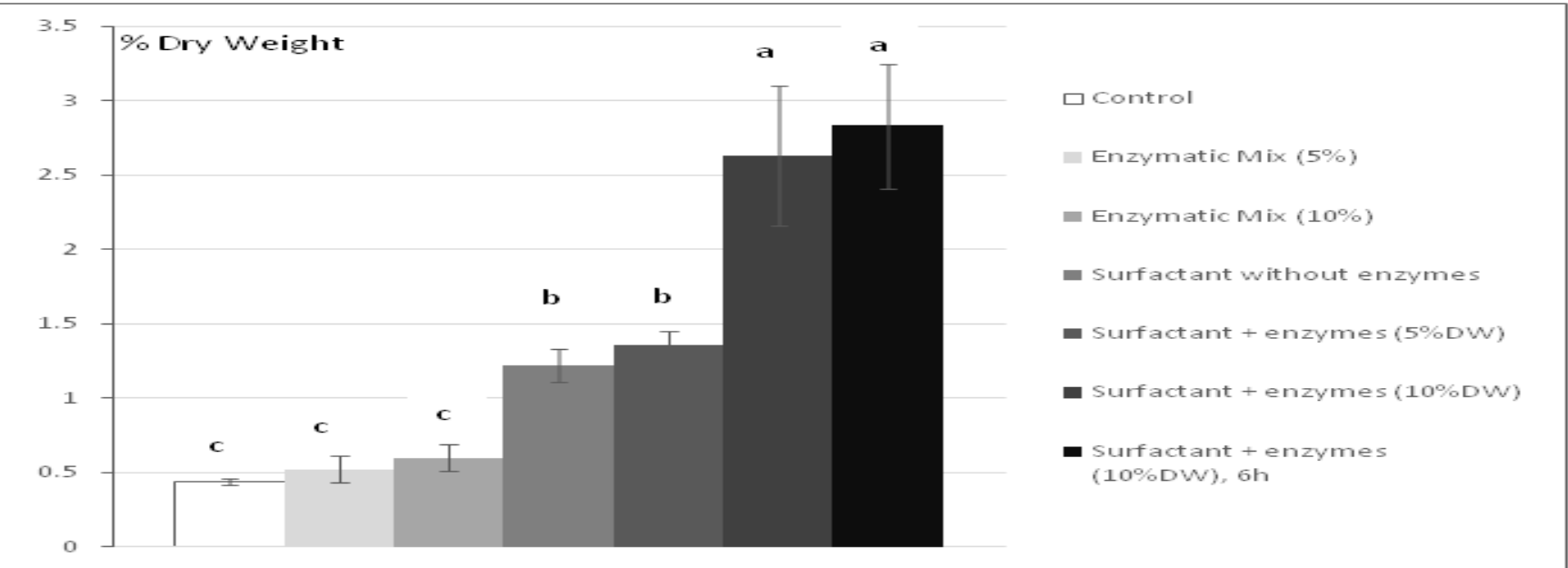

Figure 3: Effect of Triton X-100 on the solubilization of phlorotannins(quantified bythe method of Folin-Ciocalteu). Each bar represents a triplicate. Letters discriminate significantly different values.

Thus, the use of a non-ionic surfactant as the Triton X-100 during an enzymatic hydrolysis can constitute an enhancement for the extraction of phlorotannins in Sargassum muticum. With such a success, we decided to explore the potentialities of three different other surfactants commonly used in laboratories. The surfactants SDS, Tween 20 and Tween 80 were compared to Triton X-100 during a 6 hours hydrolysis with a 3\% enzyme mix. The concentration of solubilized phlorotannins in the hydrolysate was measured 10 times during the hydrolysis. The results have shown that, at the dose of $0.5 \%(\mathrm{v} / \mathrm{v})$ of surfactant, only the use of Triton X-100 constitute the significant enhancement for the solubilization of phlorotannins during the hydrolysis and not the other surfactants. In presence of Triton X-100, the final quantity of solubilized phlorotannins increased and the kinetics was accelerated: after only 30 minutes of hydrolysis, the concentration of phlorotannins has reached $1.27 \pm 0.23 \%$ DW (vs. $0.7 \pm 0.10 \%$ DW for the control without surfactant) (Figure 4).

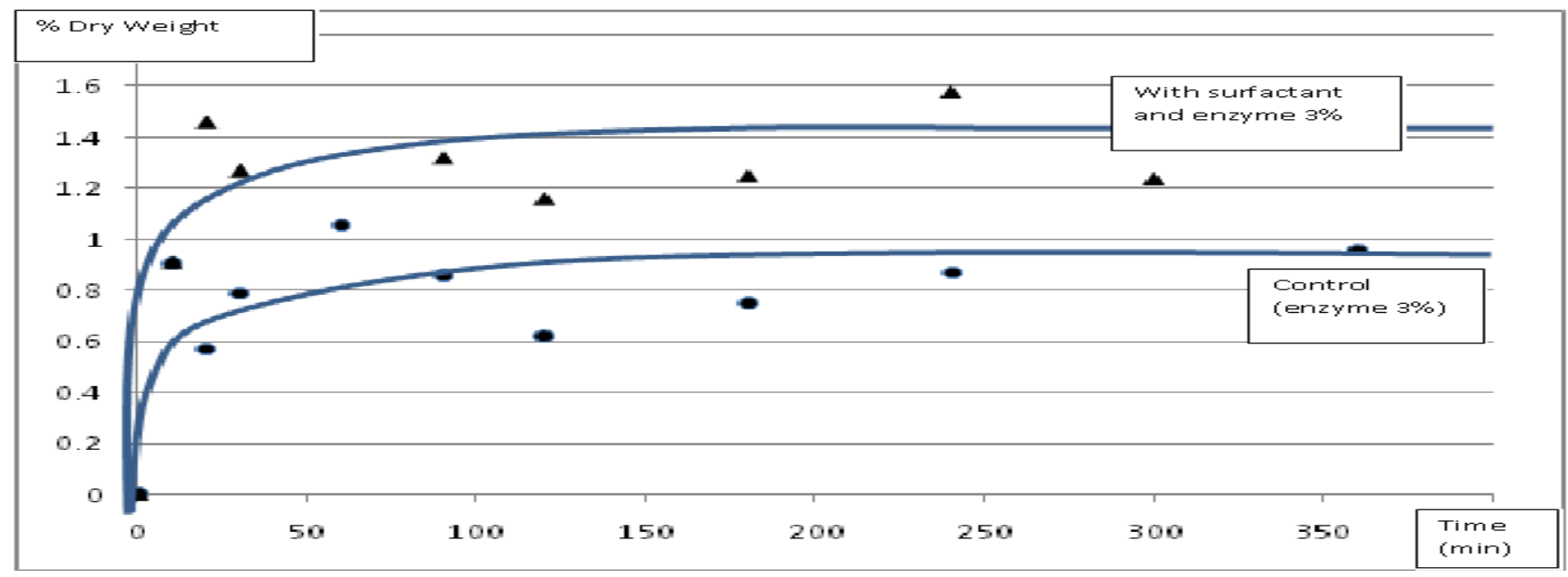

Figure 4: Effect of Triton X-100 on the kinetics of solubilization of phlorotannins during a 6 h enzymatic hydrolysis (using $1 \%$ DW Ultraflo XL ${ }^{\circledR}$, $1 \%$ DW of Protamex ${ }^{\circledR}$ and $1 \%$ DW of alginate lyase on $1 \mathrm{~g}$ of dried algae in $100 \mathrm{~mL}$ of TRIS buffer at $\mathrm{pH} 8$ ).

\section{Discussion}

The biochemical results concerning the mineral and lipidic contents of Sargassum muticum are located within the observed range in the literature ${ }^{[32]}$. The value collected for the proteic content is slightly below the values observed in other publications ${ }^{[32]}$. This observation can be explained by the collecting month (July) since the protein content is lower in summer ${ }^{[33]}$. The total extraction of phenolic compounds tends to show a more complete quantification of the phlorotannins content than previously indicated in the literature for Sargassum muticum ${ }^{[26]}$. On the other hand, this quantification with the Folin-Ciocalteu reagent is an interesting indication on the soluble/insoluble ratio. As a comparison, the Finnish authors Koivikko et a $l^{[30]}$ concluded their Folin-Ciocalteu assay on Fucus vesiculosus with a ratio soluble/insoluble of 10:1 ${ }^{[30]}$. The ratio of 2:1 that we obtained with the same protocol can be explained by a great variability between species or by a seasonal variability. Moreover, the difference of physical conditions between the south west Finland and the French Atlantic coast could explain this kind of different repartition between the secondary metabolite (as a defensive cytosolic compound) and the primary metabolite role (as a component of the cell wall) of the phlorotannins. If this ratio was confirmed throughout the year, it would be a supplementary reason to use the enzymatic assisted extraction for recovering the 
phlorotannins embedded in the cell wall as they constitute $32 \%$ of the total phenolic content.

The enzymatic strategy we chose was to use the Ultraflo XL as a mix of cellulase and hemicellulase to destructurate the cellulose fibers matrix to have access to the alginates ${ }^{[23]}$. The alginate lyase from P. alginovora was then used to solubilize the phlorotannins mainly linked to mannuronic acid regions of the alginates. The endopeptidases Protamex from Novozyme were used as an attempt to solubilize more cell wall bound phlorotannins linked to proteins and to avoid their precipitation once solubilized.

The absence of significative solubilization of phlorotannins (in comparison with the control) using 5\% DW of enzymatic mix is not specific to the enzymes used in our study as shown by Hardouin et a ${ }^{[34]}$. Even with an effective hydrolysis of polysaccharides, the solubilization of phlorotannins using commercial enzymes remains a non-effective process probably explained by the specific arrangement of the matrix and the tannic effect of the phlorotannins, complexing with proteins in the hydrolysate and then lost during the centrifugation. Hardouin et a ${ }^{[34]}$ explained their low values concerning the enzyme assisted extraction of phlorotannins on Sargassum muticum by this precipitation of the protein-phlorotannin complex. A sequencing use of different enzymes could be a solution to help enhancing the solubilization of phlorotannins but also a complexity added to a potential industrial process. The use of surfactant can avoid multiple steps treatment and the formation of phlorotannin-protein complexes. Stern $e$ a $^{[24]}$ showed that the addition of 1 to $3 \%(\mathrm{v} / \mathrm{v})$ of Triton X-100 in a mix containing proteins and phenolic compounds was sufficient to prevent any precipitation. Our results and the comparison between the control and the use of surfactant alone (Figure 3 ) showed that this effect is important and cannot be ignored concerning the enzyme assisted extraction of phlorotannins from brown algae. Moreover, we show here that non-ionic surfactant such as Triton X-100 acts in synergy with the enzymes (Figure 2) for the degradation of algal polysaccharides. This effect is documented concerning the use of surfactant as an enhancer of enzymatic activity. Eriksson et $a l^{[35]}$ showed this enhancement on the enzymatic degradation of lignocellulose and hypothesized that the surfactant prevented unproductive binding of the enzymes on the substrate. Another possibility is that the action of one of the two agents (i.e. surfactant or enzymes) allowed the other one to reach previously hidden cell wall structures thus improving the hydrolysis process. This could even be reciprocally in a way that both surfactants and the enzymes helped each other to further access to deep layers of the cell wall.

Although the addition of $5 \%$ of enzymatic mix to the $0.5 \%(\mathrm{v} / \mathrm{v})$ of surfactant is not significant concerning the solubilized phlorotannins, the content of solubilized sugars shows that a significative enzymatic hydrolysis happens and that the hydrolysis of the algal polysaccharides is clearly affected by the quantity of enzymes added to the buffer (Figure 2). Moreover, the increased concentration in phlorotannins. (Figure 3) tends to show that the use of surfactant increases the sensitivity of the process to the enzyme/ substrate ratio.

The surfactants compared in this work were chosen as the most commonly used protein solubilizing chemicals in laboratories. The comparison we made showed that, at the tested doses, the most effective surfactant for the solubilization of phlorotannins from Sargassum muticum was the Triton X-100, a non-ionic surfactant with a hydrophilic polyethylene oxide chain of 9.5 units in average. But Triton X-100 being not a food-grade surfactant, it would be of a great interest to find at least a biosourced surfactant with the same level of performance.

\section{Conclusion}

This work showed that a significant enhancement of enzymatic hydrolysis can be obtained with the use of non-ionic surfactant. Our best results were obtained with Triton X-100. This surfactant, combined to enzymatic hydrolysis, showed a synergistic effect in disrupting cell wall and solubilizing phlorotannins in Sargassum muticum. These results open new perspectives about the biorefinery of underexploited alien seaweeds. Future works or process developments should therefore be oriented on the most effective enzyme/substrate ratio and sequential enzymatic treatments, or the research of high performance biosourced surfactants.

\section{Acknowledgement}

This research was supported by the Région Pays de La Loire and the MSH AngeGuépin, France (COSELMAR project).

\section{References}

1. Ragauskas, A. J., Williams, C. K., Davison, B. H., et al. The Path Forward for Biofuels and Biomaterials. (2006) Science 311(5760): 484-489.

2. Petersen, K., Nielsen, P. V., Bertelsen, G., et al. Potential of biobased materials for food packaging. (1999) Trends in Food Science and Technology 10(2): 52-68.

3. Jung, K.A., Lim, S.R., Kim, Y. et al. Potentials of macroalgae as feedstocks for biorefinery. (2013) Bioresour Technol 135: 182-190.

4. Bourgougnon, N., Stiger, V. Chemodiversity and Bioactivity within Red and Brown Macroalgae along the French Coasts, Metropole and Overseas Department and Territories. (2011) Handbook of Marine Macroalgae : Biotechnology and Applied Phycology, ed by Kim, S-K. John Wiley \& Sons publishers 58-90.

5. Cardozo, K.H., Guaratini, T., Barros, M.P., et al. Metabolites from algae with economical impact. (2007) Comp Biochem Physiol C Toxicol Pharmicol 146(1-2): 60-78.

6. Stengel, D.B., Connan, S., Popper, Z.A. Algal chemodiversity and bioactivity : Sources of natural variability and implications for commercial application. (2011) Biotechnol Adv 29(5): 483-501.

7. Foley, P.M., Beach, E.S., Zimmerman, J.B. Algae as a source of renewable chemicals: opportunities and challenges. (2011) Green Chemistry 13(6): 1399-1405.

8. Baghel, R.S., Trivedi, N., Gupta, V., et al. Biorefining of marine macroalgal biomass for production of biofuel and commodity chemicals. (2015) Green Chemistry 17(4): 2346-2443. 
9. Francavilla, M., Franchi, M., Monteleone, M., et al. The Red Seaweed Gracilaria gracilis as a Multi Products Source. (2013) Mar Drugs 11(10): 3754-3776.

10. Balboa, E.M., Moure, A., Dominguez, H. Valorization of Sargassum muticum Biomass According to the Biorefinery Concept. (2015) Mar Drugs 13(6): 3745-3760.

11. Plouguerné, E., Le Lann, K., Connan, S., et al. Spatial and seasonal variation in density, reproductive status, length and phenolic content of the invasive brown macroalga Sargassum muticum (Yendo) Fensholt along the coast of Western Brittany (France). (2006) Aquatic Botany 85(4): 337-344.

12. Maeda, H., Hosokawa, M., Sashima, T., et al. Fucoxanthin from edible seaweed, Undaria pinnatifida, shows antiobesity effect through UCP1 expression in white adipose tissues. (2005) Biochem Biophys Res Commun 332(2): 392-397.

13. Berteau, O., Mulloy, B. Sulfated fucans, fresh perspectives: structures, functions and biological properties of sulfated fucans and an overview of enzymes active toward this class of polysaccharides. (2003) Glycobiology 13(6): 29R-40R.

14. Okada, Y., Ishimaru, A., Suzuki, R., et al. A new phloroglucinol derivative from the brown alga Eisenia bicyclis: potential for the effective treatment of diabetic complications. (2004) J Nat Prod 67(1): 103-105.

15. Heo, S.J., Hwang, J.Y., Choi, J.I., et al. Diphlorethohydroxycarmalol isolated from Ishige okamurae, a brown algae, a potent alpha-glucosidase and alpha-amylase inhibitor, alleviates postprandial hyperglycemia in diabetic mice. (2009) Eur J Pharmacol 615(1-3): 252-256.

16. Shibata, T., Ishimaru, K., Kawaguchi, S., et al. Antioxidant activities of phlorotannins isolated from Japanese Laminariaceae. (2008) J Appl Phycol 20(5): 705-711.

17. Kong, C.S., Kim, J.A., Yoon, N.Y., et al. Induction of apoptosis by phloroglucinol derivative from Ecklonia cava in MCF-7 human breast cancer cells. (2009) Food Chem Toxicol 47(7): 1653-1658.

18. Artan, M., Li, Y., Karadeniz, F., et al. Anti-HIV-1 activity of phloroglucinol derivative, 6,6'-bieckol, from Ecklonia cava. (2008) Bioorg Med Chem 16(17): 7921-7926.

19. Jung, H.A., Hyun, S.K., Kim, H.R., et al. Angiotensin-converting enzyme I inhibitory activity of phlorotannins from Ecklonia stolonifera. (2006) Fisheries Science 72(6): 1292-1299.

20. Ragan, M. A. Physodes and the Phenolic Compounds of Brown Algae. Composition and Significance of Physodes in vivo. (1976) Botanica Marina XIX: 145-154.

21. Schoenwaelder, M.E.A., Clayton, M.N. Secretion of phenolic substances into the zygote wall and cell plate in embryos of Hormosira and Acrocarpia (Fucales, Phaeophyceae). (1998) Journal of Phycology 34(6): 969-980.

22. Puri, M., Sharma, D., Barrow, C.J. Enzyme assisted extraction of bioactives from plants. (2012) Trends Biotechnol 30(1): $37-44$.

23. Deniaud-Bouët, E., Kervarec, N., Michel, G., et al. Chemical and enzymatic fractionation of cell walls from Fucales : insights into the structure of the extracellular matrix of brown algae. (2014) Ann Bot 114(6): 1203-1216.

24. Stern, J. L., Hagermann, A. E., Steinberg, P. D., et al. Phlorotannin-Protein Interactions. (1995) J Chem Ecol 22(10): $1877-1899$.

25. Ooshima, H., Sakata, M., Harano, Y. Enhancement of Enzymatic Hydrolysis of Cellulose by Surfactant. (1986) Biotechnol Bioeng 28(11): $1727-1734$.

26. Gorham, J., Lewey, S.A. Seasonal changes in the chemical composition of Sargassum muticum. (1984) Marine Biology 80(1): 103-107.

27. Dubois, M., Gilles, K.A., Hamilton, J.K., et al. Colorimetric Method for Determination of Sugars and Related Substances. (1956) Analytical Chemistry 28(3): 350-356.

28. Crooke, W.M., Simpson, W.E. Determination of ammonium in Kjeldahl digests of crops by an automated procedure. (1971) Journal of the Science of Food and Agriculture 22(1): 9-10.

29. Lourenço, S. O., Barbarino, E., De Paula, J.C., et al. Amino acid composition, protein content and calculation of nitrogen-to-protein conversion factors for 19 tropical seaweeds. (2002) Phycological Research 50(3): 233-241.

30. Koivikko, R., Loponen, J., Honkanen, T., et al. Contents of soluble, cell-wall bound and exuded phlorotannins in the brown alga Fucus vesiculosus with implications on their ecological functions. (2005) J Chem Ecol 31(1): 195-212.

31. Folch, J., Less, M., Sloane Stanley, G.H. A simple method for the isolation and purification of total lipides from animal tissues. (1957) J Biol Chem 226(1): 497-509.

32. Holdt, S.L., Kraan, S. Bioactive compounds in seaweed: functional food applications and legislation. (2011) Journal of Applied Phycology 23(3): 543-597.

33. Lewey, S.A., Gorham, J. Pigment composition and photosynthesis in Sargassum muticum. (1984) Marine Biology 80(1): 109-115.

34. Hardouin, K., Burlot, A.S., Umami, A., et al. Biochemical and antiviral activities of enzymatic hydrolysates from different invasive French seaweeds. (2014) Journal of Applied Phycology 26(2): 1029-1042.

35. Eriksson, T., Börjesson, J., Tjerneld, F. Mechanism of surfactant effect in enzymatic hydrolysis of lignocellulose. (2002) Enzyme and Microbial technology 31(3): 353-364.

Ommega Online Publishers

Journal Title: Journal of Marine Biology and Aquaculture Journal Short Name: J Marine Biol Aquacult
Journal ISSN 2381-0750

E-mail: marinelife@ommegaonline.org

Website: www.ommegaonline.org 